\title{
Performance of transplant Aman rice as influenced by tiller seedlings and nitrogen management
}

\author{
B. Kirttania, M. A. R. Sarkar and S. K. Paul* \\ Department of Agronomy, Bangladesh Agricultural University, Mymensingh-2202, Bangladesh, \\ *E-mail: skpaull@gmail.com
}

\begin{abstract}
An experiment was conducted at the Agronomy Field Laboratory, Bangladesh Agricultural University, Mymensingh during the period from July to December 2012 to observe the effect of variety, age of tiller seedling used for transplanting and nitrogen management on the yield performance of transplant Aman rice. The experiment consisted of two varieties viz. BRRI dhan49 and BRRI dhan51, two ages tiller seedling viz. 25- and 35-day old, five nitrogen management viz. control (no urea), application of prilled urea @ $215 \mathrm{~kg} \mathrm{ha}^{-1}$ (1/2 at 15 DAT+1/2 at 30 DAT), prilled urea @ $215 \mathrm{~kg} \mathrm{ha}^{-1}$ (1/3 at 15DAT+1/3 at 30DAT+1/3 at 45DAT ), urea super granules (USG) $1.8 \mathrm{~g}$ and USG $2.7 \mathrm{~g}$ four-hill $^{-1}$ in every alternate row. The experiment was laid out in randomized complete block design with three replications. The results revealed that higher plant characters, straw yield and harvest index were obtained from BRRI dhan49 compared to BRRI dhan51. Older seedlings (35-day old) produced higher grain yield to younger seedlings. The highest yield contributing characters and grain yield were obtained when $1.8 \mathrm{~g}$ USG was applied. The grain yield was highest in 35-day old tiller seedlings of BRRI dhan51 while fertilized with $1.8 \mathrm{~g}$ USG. This value was lowest when 25-day old tiller seedlings of BRRI dhan51 were fertilized with prilled urea in two split applications. It may be concluded that 35-day tiller seedlings of BRRI dhan51 fertilized with USG $1.8 \mathrm{~g}$ four-hill ${ }^{-1}$ could be used for achieving higher yield of transplant Aman rice.
\end{abstract}

Keywords: Tiller seedlings of rice, Prilled urea, USG

\section{Introduction}

The average yield of rice in Bangladesh is still low, only $2.91 \mathrm{t} \mathrm{ha}^{-1}$ which is much lower than that of other rice growing countries of the world (BBS, 2011). Food deficit is alarming in Bangladesh due to increase of population and sudden natural hazards. There is no opportunity to increase rice area to mitigate additional rice requirement. It will have to come from higher average yield on existing land through adoption of high yielding cultivars and subsequent management practices. Rice has unique ability to tiller profusely as each leaf axil has the potential to produce a tiller (Langer, 1979). The potentiality of separated tillers is reported by many researchers (Sarkar et al., 2011 and Biswas and Salokhe, 2001). In rice, many of the late tillers do not produce panicles due to higher population (Hanada, 1979). Removal of excess tillers from the mother hill at early stage could help better development for remaining tillers and the separated tillers can be used as seedling for crop production. This technique of transplanting of separated tillers may be a promising alternative for growing post-flood transplant aman rice (Mridha et al., 1991). The detached tillers can be used as seedlings especially during scarcity of seedling after flood or other natural hazards. Paul et al. (2002) reported that tillers can be separated at 25 or 35 days after transplanting (DAT) without hampering grain yield of mother plant.

Time of nitrogen application is an important aspect of overall nitrogen management in rice (Thakur, 1993). Proper timing of nitrogen application reduces the loss of nitrogen in rice fields. Efficient fertilizer management gave higher yield of crops and reduced fertilizer cost (Hossain and Islam, 1986). A number of experiments have shown that the efficiency of $\mathrm{N}$ is only about $30 \%$ of the applied fertilizer $\mathrm{N}$ and in many cases even it is less (Prasad and De Datta, 1979). However, the nature and magnitude of $\mathrm{N}$ loss largely depend upon the sources of $\mathrm{N}$ fertilizer and methods of $\mathrm{N}$ fertilizer application. The loss of nitrogen may be reduced by using deep placement of urea super granules (USG) instead of applying prilled urea. Point placement of USG can increase the efficiency of $N$ utilization by rice in wet season (Roy, 1985). To increase nitrogen use efficiency and reduce yield gap of modern rice cultivars, the right form of nitrogenous fertilizer and appropriate timing of application are very important. So the present study was undertaken to examine the influence of variety, age of tiller seedlings and nitrogen management on the performance of transplant Aman rice. 


\section{Materials and Methods}

The experiment was conducted at the Agronomy Field Laboratory, Bangladesh Agricultural University, Mymensingh to study the effect of variety, age of tiller seedling and nitrogen management on the growth and yield of transplant Aman rice. The experimental area belongs to the non-calcareous dark grey soil under Agro-ecological Zone of the Old Brahmaputra Floodplain (AEZ-9). The land was silty loam in texture having a soil $\mathrm{pH} 6.42$, moderate in organic matter content. The experiment consisted of two varieties-BRRI dhan49 and BRRI dhan51, two ages of tiller seedlings -25 and 35-day old, and five nitrogen managements-i. control, ii. application of prilled urea @ $215 \mathrm{~kg} \mathrm{ha}^{-1}(1 / 2$ at 15 DAT+1/2 at 30 DAT), iii. prilled urea @ $215 \mathrm{~kg} \mathrm{ha}^{-1}\left(1 / 3\right.$ at $15 \mathrm{DAT}+1 / 3$ at 30DAT+1/3 at 45DAT), iv. USG $1.8 \mathrm{~g}$ four-hill ${ }^{-1}$ in every alternate row and v. USG $2.7 \mathrm{~g}$ four-hill ${ }^{-1}$ in every alternate row. The experiment was laid out in a randomized complete block design with three replications. Plot size was $4.0 \mathrm{~m} \times 2.5 \mathrm{~m}$ and total number of plots was 60. Tillers were separated from 25 and 35 days after transplanting from the previously transplanted rice crop and then transplanted in the main field according to experimental plan. The experimental plots were fertilized with triple super phosphate, muriate of potash, gypsum and zinc sulphate @ 100,70, 60 and $10 \mathrm{~kg} \mathrm{ha}^{-1}$, respectively. The entire amount of fertilizers except urea was applied at final land preparation. Prilled urea and USG were applied following the specification of treatments. Five hills were randomly selected in each unit plot excluding boarder rows to record the data on yield contributing characters. Grain yield and straw yield were determined by harvesting the whole plot. The grain was threshed, cleaned, dried and then weighed. The yield of grain was adjusted to 14\% moisture content and then converted to $\mathrm{tha}^{-1}$. The recorded data were statistically analyzed using the "Analysis of Variance" technique and the differences among treatment means were adjudged by Duncan's New Multiple Range Test (Gomez and Gomez, 1984).

\section{Results and Discussion}

\section{Varietal performance}

Crop characters and yield of transplant Aman rice were significantly influenced by variety. BRRI dhan49 produced significantly taller plant $(101.42 \mathrm{~cm})$, higher number of total tillers hill ${ }^{-1}(10.27)$, longer panicle $(25.97 \mathrm{~cm})$ and grains panicle ${ }^{-1}(127.22)$ compared to BRRI dhan51. This variety produced significantly higher number of effective tillers hill $^{-1}$ (8.57) than that of BRRI dhan51 (8.09) (Table 1). These findings corroborate with those reported by Bhowmick and Nayak (2000) who stated that effective tillers hill ${ }^{-1}$ varied due to varietal difference. BRRI dhan49 produced significantly higher weight of 1000 grains (24.82 g) compared to BRRI dhan51 (Table 1). This result is in agreement with Shamsuddin et al. (1988) and Chowdhury et al. (1993) who reported differences in 1000-grain weight among the varieties. Sterile spikelets panicle ${ }^{-1}$ differed due to varietal differences, which was also reported by Chowdhury et al. (1993). Apparently BRRI dhan51 had higher grain yield (3.92 t ha-1) than BRRI dhan49 $\left(3.83 \mathrm{t} \mathrm{ha}^{-1}\right)$. Varietal differences regarding grain yield was also reported by Khisha (2002). BRRI dhan49 produced significantly higher straw yield $\left(4.21 \mathrm{t} \mathrm{ha}^{-1}\right)$ compared to BRRI dhan51 $\left(4.00 \mathrm{t} \mathrm{ha}^{-1}\right)$. These results are in conformity with that of Chowdhury et al. (1993). BRRI dhan51 produced significantly higher harvest index (49.9\%) compared to BRRI dhan49 (47.65\%). Higher grain yield was the main reason for the increased harvest index in BRRI dhan51. Tyeb et al. (2013) reported that variety had great influence on harvest index.

\section{Effect of age of tiller seedlings}

Plant characters, yield contributing characters and yield of transplant Aman rice were influenced by age of tiller seedlings. Twenty five-day old tiller seedlings produced taller plant $(101.5 \mathrm{~cm})$ than that of 35-day old tiller seedlings (Table 2). Sarkar et al. (2011) also evidenced similar results. Twenty five-day old tiller seedlings produced higher number of tillers hill $^{-1}$ (10.66) than that of 35-day old tiller seedling. Anwar and Begum (2004) reported that age of tiller seedlings significantly influenced the total number of tillers hill ${ }^{-1}$. Twenty five-day old tiller seedlings produced significantly higher number of effective tillers (8.87) and noneffective tillers hill ${ }^{-1}(1.79)$ than that of 35 -day old tiller seedlings. The longer panicle $(25.72 \mathrm{~cm})$ were obtained when 25-day old seedlings than that of 35-day old tiller seedlings (Table 2). Higher number of 
sterile spikelets panicle ${ }^{-1}$ (16.00) was obtained when 25-day old seedlings were used than that of 35-day old tiller seedlings (Table 2). Thirty five-day old tiller seedlings produced higher number of total spikelets panicle $^{-1}(143.95)$ than that of 25-day old tiller seedlings (Table 2). Differences in number of total spikelets panicle $^{-1}$ due to age of tiller seedlings were also reported by Sarkar et al. (2011). Thirty five-day old tiller seedlings produced higher 1000-grain weight $(24.96 \mathrm{~g})$ than that of 25 -day old tiller seedlings (Table 2). It was observed that 35-day old tiller seedlings produced higher grain yield than 25-old tiller seedlings (Table 2). Similar result was obtained by Biswas et al. (1987). They found the highest grain yield by transplanting tiller seedlings which were separated from mother plants 35 days after transplanting. BRRI (1988) reported that tiller could be separated at 30-40 days after transplanting (DAT). Paul et al. (2002) reported that the cultivar BR23 appeared to be resistant to tiller separation and that tillers could be separated at 25 or 35 DAT without grain yield reduction. Older (35-day old) tiller seedlings produced higher straw yield (4.21 t ha ${ }^{-1}$ ) compared to 25-day old tiller seedlings (Table 2). Higher harvest index (48.87\%) was observed in case of 25-day old tiller seedlings than that obtained from 35-old tiller seedlings (Table 2). Higher straw yield was the main reason for the reduced harvest index in case of 35day old tiller seedlings.

Table 1. Effect of variety on crop characters and yield of transplant Aman rice

\begin{tabular}{|c|c|c|c|c|c|c|c|c|c|c|c|c|}
\hline Variety & $\begin{array}{l}\text { Plant } \\
\text { height } \\
(\mathrm{cm})\end{array}$ & $\begin{array}{c}\text { No. of } \\
\text { total } \\
\text { tillers } \\
\text { hill-1 }\end{array}$ & $\begin{array}{l}\text { No. of } \\
\text { effective } \\
\text { tillers } \\
\text { hill-1 }\end{array}$ & $\begin{array}{l}\text { No. of non- } \\
\text { effective } \\
\text { tillers } \\
\text { hill-1 }^{-1}\end{array}$ & $\begin{array}{l}\text { Panicle } \\
\text { length } \\
(\mathrm{cm})\end{array}$ & $\begin{array}{c}\text { No. of } \\
\text { grains } \\
\text { panicle-1 }\end{array}$ & $\begin{array}{c}\text { No. of } \\
\text { sterile } \\
\text { spikelets } \\
\text { panicle }^{-1}\end{array}$ & $\begin{array}{l}\text { No. of total } \\
\text { spikelets } \\
\text { panicle-1 }\end{array}$ & $\begin{array}{c}1000- \\
\text { grain } \\
\text { weight }(\mathrm{g})\end{array}$ & $\begin{array}{c}\text { Grain } \\
\text { yield } \\
\left(t_{\text {ha }}^{-1}\right)\end{array}$ & $\begin{array}{l}\text { Straw } \\
\text { yield } \\
\left(\mathrm{t} \mathrm{ha} \mathrm{-}^{-1}\right)\end{array}$ & $\begin{array}{c}\text { Harvest } \\
\text { index } \\
(\%)\end{array}$ \\
\hline BRRI dhan49 & $101.425 a$ & $10.27 a$ & $8.57 a$ & 1.70 & $25.97 a$ & $127.22 a$ & $15.22 b$ & $142.44 a$ & $24.82 a$ & 3.83 & $4.21 \mathrm{a}$ & $47.65 a$ \\
\hline BRRI dhan51 & $91.162 b$ & $9.77 b$ & $8.09 b$ & 1.67 & $23.87 b$ & $124.63 b$ & $16.53 a$ & $141.16 \mathrm{~b}$ & $24.47 b$ & 3.92 & $4.00 b$ & $49.90 \mathrm{a}$ \\
\hline $\mathrm{CV}(\%)$ & 7.93 & 8.15 & 9.83 & 31.29 & 5.57 & 8.93 & 22.46 & 7.29 & 7.67 & 8.15 & 9.49 & 11.72 \\
\hline Level of sig. & * & * & * & NS & ** & * & ** & * & * & NS & * & ** \\
\hline
\end{tabular}

In a column, figures having similar letter(s) do not differ significantly whereas the figures with dissimilar letter(s) differ significantly as per DMRT

NS indicates not significant

* indicates significant at $5 \%$ level of probability

** indicates significant at $1 \%$ level of probability

Table 2. Effect of age of tiller seedling on crop characters and yield of transplant Aman rice

\begin{tabular}{|c|c|c|c|c|c|c|c|c|c|c|c|c|}
\hline $\begin{array}{l}\text { Age of tiller } \\
\text { seedling } \\
\text { (day) }\end{array}$ & $\begin{array}{l}\text { Plant } \\
\text { height } \\
(\mathrm{cm})\end{array}$ & $\begin{array}{c}\text { Total } \\
\text { tillers } \\
\text { hill-1 }^{-1}\end{array}$ & $\begin{array}{l}\text { Effective } \\
\text { tillers } \\
\text { hill-1 }^{-1}\end{array}$ & $\begin{array}{c}\text { Non- } \\
\text { effective } \\
\text { tillers } \\
\text { hill-1 }^{-1}\end{array}$ & $\begin{array}{l}\text { Panicle } \\
\text { length } \\
(\mathrm{cm})\end{array}$ & $\begin{array}{c}\text { Grains } \\
\text { panicle- }^{-1}\end{array}$ & $\begin{array}{c}\text { Sterile } \\
\text { spikelets } \\
\text { panicle-1 }^{-1}\end{array}$ & $\begin{array}{c}\text { Total } \\
\text { spikelets } \\
\text { panicle-1 }^{-1}\end{array}$ & $\begin{array}{l}1000- \\
\text { grain wt } \\
\text { (g) }\end{array}$ & $\begin{array}{c}\text { Grain } \\
\text { yield } \\
(\mathrm{t} \text { ha-1) }\end{array}$ & $\begin{array}{l}\text { Straw } \\
\text { yield } \\
\left(\mathrm{t} \mathrm{ha} \mathrm{-}^{-1}\right)\end{array}$ & $\begin{array}{c}\text { Harvest } \\
\text { index } \\
(\%)\end{array}$ \\
\hline 25 & $101.50 \mathrm{a}$ & $10.66 \mathrm{a}$ & $8.87 a$ & $1.79 a$ & $25.72 a$ & 123.65 & $16.00 \mathrm{a}$ & $139.66 \mathrm{~b}$ & $24.34 b$ & $3.80 \mathrm{~b}$ & $4.00 \mathrm{~b}$ & $48.87 a$ \\
\hline 35 & $91.08 \mathrm{~b}$ & $9.38 b$ & $7.80 \mathrm{~b}$ & $1.58 b$ & $24.12 b$ & 128.19 & $15.75 b$ & 143.95a & $24.96 a$ & $3.95 a$ & $4.21 \mathrm{a}$ & $48.68 b$ \\
\hline CV(\%) & 7.93 & 8.15 & 9.83 & 31.29 & 5.57 & 8.93 & 22.46 & 7.29 & 7.67 & 8.15 & 9.49 & 11.72 \\
\hline Level of sig. & NS & * & * & NS & * & NS & * & * & * & * & ** & * \\
\hline
\end{tabular}

In a column, figures having similar letter(s) do not differ significantly whereas the figures with dissimilar letter(s) differ significantly as per DMRT

NS indicates not significant

* indicates significant at $5 \%$ level of probability

** indicates significant at $1 \%$ level of probability

\section{Effect of nitrogen management}

Plant height was not significantly affected by nitrogen management. Numerically the tallest plant (98.82 $\mathrm{cm})$ was produced when prilled urea was applied in three splits $(1 / 3$ at15 DAT+1/3 at $30 \mathrm{DAT}+1 / 3$ at 45DAT) and the shortest plant height $(94.78 \mathrm{~cm})$ was produced when prilled urea was applied in two splits (1/2 at 15 DAT+1/2 at 30 DAT) (Table 3). Number of total tillers hill ${ }^{-1}$, number of effective tillers hill ${ }^{-1}$, number of non-effective tillers hill $^{-1}$, panicle length, number of sterile spikelets panicle ${ }^{-1}, 1000$-grain weight, grain yield, straw yield and harvest index was significantly influenced by nitrogen management. The highest number of tillers hill ${ }^{-1}(14.10)$ was produced by application of USG $1.8 \mathrm{~g}$ four-hill ${ }^{-1}$ in every alternate row and the lowest one (7.55) was produced by the application of prilled urea in two splits (Table 3). The highest number of effective tillers hill ${ }^{-1}$ (12.92) was produced by application of USG $1.8 \mathrm{~g}$ four-hill ${ }^{-1}$ in every alternate row and the lowest (5.77) was produced by application of prilled urea in two 
splits (Table 3). The highest number of non-effective tillers hill ${ }^{-1}(2.09)$ was produced when urea was not applied and the lowest (1.18) was produced by application of USG $1.8 \mathrm{~g}$ four-hill ${ }^{-1}$ in every alternate row (Table 3). The longest panicle $(28.79 \mathrm{~cm}$ ) was produced by application of USG $1.8 \mathrm{~g}$ per four hill in every alternate row and the shortest one $(23.36 \mathrm{~cm}$ ) was observed in prilled urea in two splits (Table 3). These differences were also found by Rahman (2003) who reported that panicle length differed significantly due to level of USG. The highest number of grains panicle ${ }^{-1}$ (138.3) was produced by application of USG $1.8 \mathrm{~g}$ and the lowest number of grains panicle ${ }^{-1}$ (120.4) was produced by application of prilled urea in three splits (Table 3). The highest number of sterile spikelets panicle ${ }^{-1}$ (18.32) was produced from the application of prilled urea in two splits and the lowest one (13.35) was produced in control (Table 3). The highest total number of spikelets (150.8) was produced when USG $1.8 \mathrm{~g}$ was applied and the lowest (138.4) was produced when prilled urea was applied in three splits (Table 3). The highest 1000-grain weight $(25.96 \mathrm{~g})$ was produced from the application of USG $1.8 \mathrm{~g}$ and the lowest one $(23.50 \mathrm{~g})$ was produced by the application of prilled urea in three splits (Table 3). The highest grain yield $\left(4.48 \mathrm{t} \mathrm{ha}^{-1}\right)$ was produced from the application of USG $1.8 \mathrm{~g}$ followed by application of USG $2.7 \mathrm{~g}$ and the lowest grain yield $\left(3.38 \mathrm{t} \mathrm{ha}^{-1}\right)$ was produced by the application of prilled urea in two splits (Table 3 ). USG releases nitrogen slowly in the soil providing a steady supply of available nitrogen throughout the growing period of rice that might be the probable reason for higher grain yield. The highest number of effective tillers hill ${ }^{-1}$ and the highest weight of 1000 grains in USG $1.8 \mathrm{~g}$ were mainly responsible for the highest grain yield in this treatment (USG 1.8g). Ahmed et al. (2000) found that placement of USG @ $160 \mathrm{~kg} \mathrm{~N}$ $\mathrm{ha}^{-1}$ produced the highest grain yield. Visually the highest straw yield $\left(4.61 \mathrm{t} \mathrm{ha}^{-1}\right)$ was produced from the application of USG $1.8 \mathrm{~g}$ and the lowest straw yield $\left(3.81 \mathrm{t} \mathrm{ha}^{-1}\right.$ ) by the application of prilled urea (Table 3). The highest harvest index (49.35\%) was produced from application of prilled urea in three splits and the lowest harvest index (47.22\%) was produced from the application of prilled urea in two splits (Table 3).

Table 3. Effect of nitrogen management on crop characters and yield of transplant Aman rice

\begin{tabular}{|c|c|c|c|c|c|c|c|c|c|c|c|c|}
\hline Nitrogen management & $\begin{array}{l}\text { Plant } \\
\text { height } \\
(\mathrm{cm})\end{array}$ & $\begin{array}{l}\text { Total } \\
\text { tillers } \\
\text { hill-1 }^{-1}\end{array}$ & $\begin{array}{l}\text { Effective } \\
\text { tillers } \\
\text { hill-1 }^{-1}\end{array}$ & $\begin{array}{l}\text { Non- } \\
\text { effective } \\
\text { tillers hill-1 }\end{array}$ & $\begin{array}{l}\text { Panicle } \\
\text { length } \\
\text { (cm) }\end{array}$ & $\begin{array}{c}\text { Grains } \\
\text { panicle-1 }^{-1}\end{array}$ & $\begin{array}{l}\text { Sterile } \\
\text { spikelets } \\
\text { panicle-1 }^{-1}\end{array}$ & $\begin{array}{c}\text { Total } \\
\text { spikelets } \\
\text { panicle }^{-1}\end{array}$ & $\begin{array}{l}1000- \\
\text { grain wt } \\
\text { (g) }\end{array}$ & $\begin{array}{l}\text { Grain } \\
\text { yield } \\
\left(\mathrm{t} \mathrm{ha}^{-1}\right)\end{array}$ & $\begin{array}{l}\text { Straw } \\
\text { yield } \\
\left(\mathrm{t} \mathrm{ha}^{-1}\right)\end{array}$ & $\begin{array}{c}\text { Harvest } \\
\text { index } \\
(\%)\end{array}$ \\
\hline Control ( no urea) & 95.88 & $11.30 \mathrm{~b}$ & $9.20 \mathrm{~b}$ & $2.09 a$ & $24.41 \mathrm{~b}$ & $126.7 \mathrm{~b}$ & $13.35 \mathrm{~b}$ & $140.0 \mathrm{~b}$ & $24.86 \mathrm{ab}$ & $3.87 \mathrm{bc}$ & 4.12 & 48.67 \\
\hline $\begin{array}{l}\text { Prilled urea (1/2 at } 15 \\
\text { DAT+1/2 at } 30 \text { DAT) }\end{array}$ & 94.78 & $7.55 \mathrm{c}$ & $5.77 d$ & $1.78 a b$ & $23.36 \mathrm{~b}$ & $121.0 \mathrm{~b}$ & $18.32 a$ & $139.3 b$ & $23.50 \mathrm{~b}$ & $3.38 \mathrm{c}$ & 3.81 & 47.22 \\
\hline $\begin{array}{c}\text { Prilled urea ( } 1 / 3 \text { at } 15 \\
\text { DAT+1/3 at } 30 \text { DAT }+1 / 3 \\
\text { at } 45 \mathrm{DAT})\end{array}$ & 98.82 & $8.93 \mathrm{c}$ & $7.29 c$ & $1.64 b$ & $23.69 b$ & $120.4 b$ & $17.99 a$ & $138.4 b$ & $24.33 b$ & $3.73 \mathrm{bc}$ & 3.94 & 49.35 \\
\hline USG $1.8 \mathrm{~g}$ & 95.02 & $14.10 \mathrm{a}$ & $12.92 \mathrm{a}$ & $1.18 \mathrm{c}$ & $28.79 a$ & $138.3 a$ & $12.50 \mathrm{~b}$ & $150.8 \mathrm{a}$ & $25.96 a$ & $4.48 \mathrm{a}$ & 4.61 & 49.37 \\
\hline USG $2.7 \mathrm{~g}$ & 96.95 & $8.22 \mathrm{c}$ & $6.49 \mathrm{~cd}$ & $1.73 a b$ & $24.36 \mathrm{~b}$ & $123.3 \mathrm{~b}$ & $17.24 a$ & $140.5 b$ & $24.61 \mathrm{ab}$ & $3.92 b$ & 4.04 & 49.26 \\
\hline $\mathrm{CV}(\%)$ & 7.93 & 8.15 & 9.83 & 31.29 & 5.57 & 8.93 & 22.46 & 7.29 & 7.67 & 8.15 & 9.49 & 11.72 \\
\hline Level of sig. & NS & & & ** & * & ** & * & * & * & ** & NS & NS \\
\hline
\end{tabular}

In a column, figures having similar letter(s) do not differ significantly whereas the figures with dissimilar letter(s) differ significantly as per DMRT

NS indicates not significant

* indicates significant at $5 \%$ level of probability

** indicates significant at $1 \%$ level of probability

\section{Interaction effect}

Panicle length was significantly affected by the interaction between variety and age of tiller seedling. The longest panicle $(27.18 \mathrm{~cm}$ ) was obtained when 25-day old tiller seedlings of BRRI dhan49 were planted and the shortest $(23.48 \mathrm{~cm})$ was obtained when 35-day old tiller seedlings of BRRI dhan51 variety were planted (Table 4). Panicle length, 1000-grain weight, grain yield, straw yield and harvest index were significantly influenced by the interaction of variety and nitrogen management. The longest panicle (28.95 $\mathrm{cm}$ ) was obtained from the application of USG $2.7 \mathrm{~g}$ in BRRI dhan49 and the shortest panicle $(22.10 \mathrm{~cm})$ was obtained from the control in BRRI dhan51 (Table 5). The highest1000-grain weight (28.63g) was obtained in BRRI dhan49 fertilized with prilled urea in three splits and lowest one (22.54) was obtained in BRRI dhan49 with control (Table 5). The highest grain yield (4.50 t ha $\left.{ }^{-1}\right)$ was obtained in BRRI dhan51 and application of USG $2.7 \mathrm{~g}$ and the lowest $\left(3.33 \mathrm{tha}^{-1}\right)$ was obtained due to the interaction of BRRI dhan49 in control (Table 5). The highest straw yield $\left(4.65 \mathrm{tha}^{-1}\right)$ was obtained in BRRI dhan49 was 
planted applying USG $2.7 \mathrm{~g}$ and the lowest straw yield $\left(3.5 \mathrm{t} \mathrm{ha}^{-1}\right)$ was obtained in BRRI dhan51 fertilized with prilled urea in two splits (Table 5). The highest harvest index (51.57\%) was obtained in BRRI dhan51 with control and the lowest harvest index (44.4\%) was obtained when in BRRI dhan49 was planted and prilled urea in two splits (Table 5).

Table 4. Effect of interaction of variety and age of tiller seedlings on crop characters and yield of transplant Aman rice

\begin{tabular}{|c|c|c|c|c|c|c|c|c|c|c|c|c|}
\hline $\begin{array}{c}\text { Interaction } \\
\text { (variety X age } \\
\text { of tiller } \\
\text { seedlings) }\end{array}$ & $\begin{array}{c}\text { Plant } \\
\text { height }(\mathrm{cm})\end{array}$ & \begin{tabular}{|c} 
No. of \\
total tillers \\
hill-1
\end{tabular} & $\begin{array}{c}\text { No. of } \\
\text { effective } \\
\text { tillers hill-1 }\end{array}$ & $\begin{array}{l}\text { No. of non- } \\
\text { effective } \\
\text { tillers } \\
\text { hill-1 }\end{array}$ & $\begin{array}{l}\text { Panicle } \\
\text { length } \\
\text { (cm) }\end{array}$ & $\begin{array}{c}\text { No. of } \\
\text { grains } \\
\text { panicle-1 }\end{array}$ & $\begin{array}{c}\text { No. of } \\
\text { sterile } \\
\text { spikelets } \\
\text { panicle-1 }\end{array}$ & \begin{tabular}{|c} 
No. of total \\
spikelets \\
panicle-1
\end{tabular} & $\begin{array}{c}1000- \\
\text { grain } \\
\text { weight }(\mathrm{g})\end{array}$ & $\begin{array}{l}\text { Grain } \\
\text { yield } \\
\left(\mathrm{t} \mathrm{ha}^{-1}\right)\end{array}$ & $\begin{array}{c}\text { Straw } \\
\text { yield } \\
\left(\mathrm{t} \mathrm{ha}^{-1}\right)\end{array}$ & $\begin{array}{c}\text { Harvest } \\
\text { index } \\
(\%)\end{array}$ \\
\hline $\mathrm{V}_{1} \times \mathrm{A}_{1}$ & 108.06 & 10.78 & 8.98 & 1.80 & $27.18 \mathrm{a}$ & 126.61 & 14.90 & 141.51 & 24.76 & 3.82 & 4.17 & 47.886 \\
\hline$V_{1} \times A_{2}$ & 94.78 & 10.78 & 8.17 & 1.59 & $24.77 \mathrm{~b}$ & 127.83 & 15.53 & 143.36 & 24.88 & 3.84 & 4.25 & 47.42 \\
\hline $\mathrm{V}_{2} \times \mathrm{A}_{1}$ & 94.93 & 10.54 & 8.76 & 1.78 & $24.26 \mathrm{bc}$ & 120.70 & 17.10 & 137.80 & 23.92 & 3.78 & 3.84 & 49.85 \\
\hline $\mathrm{V}_{2} \times \mathrm{A}_{2}$ & 87.38 & 9.00 & 7.43 & 1.56 & $23.48 \mathrm{c}$ & 128.56 & 15.96 & 144.53 & 25.03 & 4.05 & 4.16 & 49.94 \\
\hline CV (\%) & 7.93 & 8.15 & 9.83 & 31.29 & 5.57 & 8.93 & 22.46 & 7.29 & 7.67 & 8.15 & 9.49 & 11.72 \\
\hline Level of sig. & NS & NS & NS & NS & * & NS & NS & NS & NS & NS & NS & NS \\
\hline
\end{tabular}

In a column, figures having similar letter(s) do not differ significantly whereas the figures with dissimilar letter(s) differ significantly as per DMRT

NS indicates not significant

* indicates significant at $5 \%$ level of probability

** indicates significant at $1 \%$ level of probability

$$
\begin{array}{ll}
\mathrm{V}_{1}=\mathrm{BRRI} \text { dhan49 } & \mathrm{A}_{1}=\text { 25-day old tiller seedling } \\
\mathrm{V}_{2}=\text { BRRI dhan51 } & \mathrm{A}_{2}=\text { 35-day old tiller seedling }
\end{array}
$$

\begin{tabular}{|c|c|c|c|c|c|c|c|c|c|c|c|c|}
\hline $\begin{array}{c}\text { Interaction } \\
\text { (variety } \mathrm{X} \text { nitrogen } \\
\text { management) }\end{array}$ & $\begin{array}{l}\text { Plant } \\
\text { height } \\
(\mathrm{cm})\end{array}$ & $\begin{array}{c}\text { No. of } \\
\text { total } \\
\text { tillers } \\
\text { hill- }^{-1}\end{array}$ & $\begin{array}{l}\text { No. of } \\
\text { effective } \\
\text { tillers hill-1 }\end{array}$ & $\begin{array}{l}\text { No. of non- } \\
\text { effective } \\
\text { tillers } \\
\text { hill-1 }\end{array}$ & $\begin{array}{l}\text { Panicle } \\
\text { length } \\
\text { (cm) }\end{array}$ & $\begin{array}{c}\text { No. of } \\
\text { grains } \\
\text { panicle-1 }\end{array}$ & $\begin{array}{c}\text { No. of } \\
\text { sterile } \\
\text { spikelets } \\
\text { panicle-1 }^{-1}\end{array}$ & \begin{tabular}{|c|} 
No. of total \\
spikelets \\
panicle-1
\end{tabular} & $\begin{array}{l}1000- \\
\text { grain } \\
\text { weight } \\
\text { (g) }\end{array}$ & $\begin{array}{l}\text { Grain } \\
\text { yield } \\
\left(\mathrm{t} \mathrm{ha}^{-1}\right)\end{array}$ & $\begin{array}{l}\text { Straw } \\
\text { yield } \\
\left(\mathrm{t} \mathrm{ha}^{-1}\right)\end{array}$ & $\begin{array}{c}\text { Harvest } \\
\text { index } \\
(\%)\end{array}$ \\
\hline $\mathrm{V}_{1} \times \mathrm{N}_{1}$ & 104.86 & 9.65 & 7.91 & 1.73 & $25.28 \mathrm{bc}$ & 117.79 & 17.68 & 135.47 & $22.54 \mathrm{~d}$ & $3.33 d$ & $3.75 \mathrm{ab}$ & 47.12ab \\
\hline $\mathrm{V}_{1} \times \mathrm{N}_{2}$ & 98.37 & 7.26 & 5.40 & 1.86 & $24.09 \mathrm{~cd}$ & 122.29 & 17.31 & 139.60 & $24.05 \mathrm{bcd}$ & $3.29 d$ & $4.12 a b$ & $44.40 \mathrm{~b}$ \\
\hline $\mathrm{V}_{1} \times \mathrm{N}_{3}$ & 101.03 & 12.56 & 10.35 & 2.21 & $25.35 \mathrm{bc}$ & 131.50 & 12.88 & 144.39 & $28.63 a$ & $4.01 \mathrm{abcd}$ & $4.45 \mathrm{ab}$ & $47.87 a b$ \\
\hline $\mathrm{V}_{1} \times \mathrm{N}_{4}$ & 103.25 & 7.58 & 6.15 & 1.43 & $26.2 b$ & 125.53 & 15.67 & 141.21 & $25.73 a b$ & $4.07 a b c$ & $4.08 \mathrm{ab}$ & 49.76ab \\
\hline $\mathrm{V}_{1} \times \mathrm{N}_{5}$ & 99.60 & 14.31 & 13.06 & 1.25 & $28.95 a$ & 138.98 & 12.55 & 151.53 & $26.27 a$ & $4.46 a b$ & $4.65 a$ & 49.12ab \\
\hline $\mathrm{V}_{2} \times \mathrm{N}_{1}$ & 92.77 & 8.22 & 6.67 & 1.55 & $22.10 \mathrm{e}$ & 123.01 & 18.28 & 141.30 & 26.12ab & 4.14abc & $4.13 a b$ & $51.57 \mathrm{a}$ \\
\hline $\mathrm{V}_{2} \mathrm{XN}_{2}$ & 91.19 & 7.85 & 6.15 & 1.70 & $22.63 \mathrm{de}$ & 119.77 & 19.32 & 139.09 & $22.94 \mathrm{~d}$ & $3.47 c d$ & $3.50 \mathrm{~b}$ & $50.04 a b$ \\
\hline $\mathrm{V}_{2} \mathrm{XN}_{3}$ & 90.72 & 10.03 & 8.06 & 1.96 & 23.48de & 121.80 & 13.81 & 135.61 & 24.18abcd & $3.72 \mathrm{~cd}$ & $3.80 \mathrm{ab}$ & $49.47 a b$ \\
\hline $\mathrm{V}_{2} \mathrm{XN}_{4}$ & 90.66 & 8.86 & 6.83 & 2.03 & 22.51de & 120.98 & 18.79 & 139.78 & $23.50 \mathrm{~cd}$ & $3.76 \mathrm{bcd}$ & $4.00 \mathrm{ab}$ & 48.77ab \\
\hline $\mathrm{V}_{2} \mathrm{XN}_{5}$ & 90.45 & 13.88 & 12.76 & 1.11 & $28.63 a$ & 137.60 & 12.45 & 150.05 & $25.65 a b c$ & $4.50 \mathrm{a}$ & $4.57 a b$ & $49.63 a b$ \\
\hline CV (\%) & 7.93 & 8.15 & 9.83 & 31.29 & 5.57 & 8.93 & 22.46 & 7.29 & 7.67 & 8.15 & 9.49 & 11.72 \\
\hline Level of sig. & NS & NS & NS & NS & * & NS & NS & NS & ** & $* *$ & * & * \\
\hline
\end{tabular}

Table 5. Effect of interaction of variety and nitrogen management on crop characters and yield of transplant Aman rice

In a column, figures having similar letter(s) do not differ significantly whereas the figures with dissimilar letter(s) differ significantly as per DMRT

NS indicates not significant $\quad \mathrm{V}_{1}=\mathrm{BRRI}$ dhan $49 \quad \mathrm{~N}_{1}=$ Control ( no urea)

* indicates significant at $5 \%$ level of probability $\quad V_{2}=$ BRRI dhan $51 \quad N_{2}=$ Prilled urea $(1 / 2$ at 15 DAT+1/2 at 30 DAT)

** indicates significant at $1 \%$ level of probability

$\mathrm{N}_{3}=$ Prilled urea (1/3 at15 DAT+1/3 at $30 \mathrm{DAT}+1 / 3$ at45DAT)

$\mathrm{N}_{4}=$ USG $1.8 \mathrm{~g}, \mathrm{~N}_{5}=$ Application of USG $2.7 \mathrm{~g}$

Crop characters and yield were also influenced by the interaction between age of tiller seedlings and nitrogen management. The highest number of total tillers hill ${ }^{-1}(14.17)$ was obtained in of 35-day old tiller seedlings fertilized with USG $2.7 \mathrm{~g}$ and the lowest one (8.03) was obtained in 25-day old tiller seedlings fertilized with USG $1.8 \mathrm{~g}$ (Table 6). The longest panicle $(28.80 \mathrm{~cm}$ ) was obtained due to the interaction of 35 -day old tiller seedlings and application of USG $2.7 \mathrm{~g}$ and the shortest panicle $(22.44 \mathrm{~cm})$ was obtained due to the interaction of 35-day old tiller seedlings in three split application of prilled urea (Table 6). The highest number of grains panicle ${ }^{-1}$ (138.4) was obtained when 25-day old tiller seedlings were planted applying USG $2.7 \mathrm{~g}$ and the lowest number of grains panicle ${ }^{-1}$ (110.4) was obtained when 25-day old tiller seedlings were planted in control (Table 6). The highest number of total spikelets (150.8) was obtained in 25-day old tiller seedlings were planted applying USG $2.7 \mathrm{~g}$ and the lowest (129.9) was obtained when 25 -day old tiller seedlings with control (Table 6). The highest 1000 -grain weight (26.03g) was obtained in 35-day old tiller seedlings fertilized with USG $2.7 \mathrm{~g}$ and the lowest one (22.43g) was obtained in 25-day 
old tiller seedlings fertilized with prilled urea in two splits (Table 6). The highest grain yield (4.48 $\mathrm{t} \mathrm{ha}^{-1}$ ) was obtained due to the interaction of 25-day old tiller seedlings fertilized with USG $2.7 \mathrm{~g}$ and the lowest one $\left(2.97 \mathrm{t} \mathrm{ha}^{-1}\right)$ was obtained in 25-day old tiller seedlings with two splits of prilled urea (Table 6). The highest straw yield $\left(4.75 \mathrm{t} \mathrm{ha}^{-1}\right)$ was obtained in 35-day old tiller seedlings fertilized with USG $2.7 \mathrm{~g}$ and the lowest straw yield $\left(3.45 \mathrm{t} \mathrm{ha}^{-1}\right)$ was obtained in 25-day old tiller seedlings under control treatment (Table 6).

Table 6. Effect of interaction of age of tiller seedlings and nitrogen management on crop characters and yield of transplant Aman rice

\begin{tabular}{|c|c|c|c|c|c|c|c|c|c|c|c|c|}
\hline $\begin{array}{l}\text { Interaction } \\
\text { (age of tiller } \\
\text { seedlings } \times \text { nitrogen } \\
\text { management) }\end{array}$ & $\begin{array}{l}\text { Plant } \\
\text { height } \\
(\mathrm{cm})\end{array}$ & $\begin{array}{c}\text { No. of } \\
\text { total } \\
\text { tillers } \\
\text { hill-1 } \\
\end{array}$ & $\begin{array}{l}\text { No. of. } \\
\text { effective } \\
\text { tillers hill-1 }\end{array}$ & $\begin{array}{l}\text { No. of non- } \\
\text { effective } \\
\text { tillers } \\
\text { hill-1 }\end{array}$ & $\begin{array}{l}\text { Panicle } \\
\text { length } \\
(\mathrm{cm})\end{array}$ & $\begin{array}{l}\text { No. of } \\
\text { grains } \\
\text { panicle-1 }\end{array}$ & $\begin{array}{l}\text { No. of } \\
\text { sterile } \\
\text { spikelets } \\
\text { panicle-1 } \\
\end{array}$ & $\begin{array}{l}\text { No. of total } \\
\text { spikelets } \\
\text { panicle-1 }\end{array}$ & $\begin{array}{c}1000- \\
\text { grain } \\
\text { weight } \\
(\mathrm{g})\end{array}$ & $\begin{array}{l}\text { Grain } \\
\text { yield } \\
\left(\mathrm{t} \mathrm{ha}^{-1}\right)\end{array}$ & $\begin{array}{c}\text { Straw } \\
\text { yield } \\
\left(\mathrm{t} \mathrm{ha}^{-1}\right)\end{array}$ & $\begin{array}{c}\text { Harvest } \\
\text { index } \\
(\%)\end{array}$ \\
\hline$A_{1} \times N_{1}$ & 102.82 & $9.57 \mathrm{~b}$ & 7.92 & 1.65 & $24.47 c d$ & $110.4 d$ & 19.56 & $129.9 d$ & $23.27 \mathrm{bc}$ & $3.25 \mathrm{~cd}$ & $3.45 b$ & 48.96 \\
\hline $\mathrm{A}_{1} \times \mathrm{N}_{2}$ & 105.26 & $8.25 b c$ & 6.41 & 1.83 & $24.05 \mathrm{cde}$ & $114.9 \mathrm{~cd}$ & 18.98 & $133.8 \mathrm{~cd}$ & $22.43 c$ & $2.97 \mathrm{~d}$ & $3.71 \mathrm{ab}$ & 45.04 \\
\hline$A_{1} \times N_{3}$ & 101.54 & $13.43 a$ & 10.85 & 2.58 & $26.38 b$ & 131.2ab & 12.73 & 143.9abc & $25.49 a$ & $4.21 a b$ & $4.31 a b$ & 50.11 \\
\hline$A_{1} \times N_{4}$ & 100.20 & $8.03 b c$ & 6.36 & 1.66 & $24.93 b c$ & $123.5 b c$ & 16.31 & 139.8abcd & $24.49 a b c$ & $4.10 a b$ & $4.08 a b$ & 50.10 \\
\hline$A_{1} \times N_{5}$ & 97.66 & $14.03 a$ & 12.80 & 1.23 & $28.78 a$ & $138.4 a$ & 12.41 & $150.8 \mathrm{a}$ & $26.03 a$ & $4.48 \mathrm{a}$ & $4.46 \mathrm{ab}$ & 50.14 \\
\hline $\mathrm{A}_{2} \times \mathrm{N}_{1}$ & 94.81 & $8.30 \mathrm{bc}$ & 6.66 & 1.63 & 22.92de & 130.4ab & 16.40 & 146.9ab & $25.38 \mathrm{ab}$ & $4.22 a b$ & $4.43 \mathrm{ab}$ & 49.74 \\
\hline $\mathrm{A}_{2} \mathrm{XN}_{2}$ & 84.30 & $6.86 c$ & 5.13 & 1.73 & $22.67 \mathrm{e}$ & 127.2abc & 17.64 & 144.9abc & $24.56 \mathrm{abc}$ & 3.79abc & $3.91 \mathrm{ab}$ & 49.40 \\
\hline $\mathrm{A}_{2} \mathrm{XN}_{3}$ & 90.21 & $9.16 \mathrm{~b}$ & 7.56 & 1.60 & $22.44 \mathrm{e}$ & $122.1 \mathrm{bcd}$ & 13.96 & $136.1 \mathrm{bcd}$ & $24.23 a b c$ & $3.52 \mathrm{bcd}$ & $3.94 \mathrm{ab}$ & 47.22 \\
\hline $\mathrm{A}_{2} \times \mathrm{N}_{4}$ & 93.71 & $8.41 \mathrm{bc}$ & 6.61 & 1.80 & 23.78cde & $123.0 \mathrm{bcd}$ & 18.16 & 141.2abcd & $24.73 a b$ & $3.73 \mathrm{bc}$ & $4.00 \mathrm{ab}$ & 48.43 \\
\hline $\mathrm{A}_{2} \mathrm{XN}_{5}$ & 92.38 & $14.17 \mathrm{a}$ & 13.03 & 1.13 & $28.80 \mathrm{a}$ & $138.2 a$ & 12.58 & $150.8 \mathrm{a}$ & $25.88 a$ & $4.48 \mathrm{a}$ & $4.75 \mathrm{a}$ & 48.61 \\
\hline CV (\%) & 7.93 & 8.15 & 9.83 & 31.29 & 5.57 & 8.93 & 22.46 & 7.29 & 7.67 & 8.15 & 9.49 & 11.72 \\
\hline Level of sig. & NS & * & NS & NS & * & & NS & * & ** & & * & NS \\
\hline
\end{tabular}

In a column, figures having similar letter(s) do not differ significantly whereas the figures with dissimilar letter(s) differ significantly as per DMRT

NS indicates not significant $\quad A_{1}=25$-day old tiller seedling; $N_{1}=$ Control (no urea)

* indicates significant at $5 \%$ level of probability $A 2=35$-day old tiller seedling; $N_{2}=$ Prilled urea(1/2 at15 DAT+1/2 at 30 DAT)

** indicates significant at $1 \%$ level of probability

$\mathrm{N}_{3}=$ Prilled urea (1/3 at15 DAT+1/3 at 30 DAT45DAT) $\mathrm{N}_{4}=$ USG $1.8 \mathrm{~g}, \mathrm{~N}_{5}=$ USG $2.7 \mathrm{~g}$

The interaction of variety, age of tiller seedlings and nitrogen management significantly influenced crop characters and yield of transplant Aman rice. The highest number of total tillers hill ${ }^{-1}$ (14.47) was obtained due to the interaction of BRRI dhan49, 35-day old tiller seedlings and application of $2.7 \mathrm{~g}$ USG and the lowest one (5.80) was obtained in 35-day old tiller seedlings of BRRI dhan51 fertilized with prilled urea in two splits (Table 7). Number of effective tillers hill ${ }^{-1}$ ranged from 4.46 to 13.23 . The highest number of effective tillers hill ${ }^{-1}$ was obtained due to the interaction of 35-day old seedling and application of USG $2.7 \mathrm{~g}$ in BRRI dhan49 while the lowest one (4.46) was obtained due to the interaction of 35-day old seedling and application of prilled urea in two splits in BRRI dhan51 (Table 7). The highest number of grains panicle $^{-1}$ (139.13) was obtained in 35-day old tiller seedlings of BRRI dhan49 fertilized with USG 2.7g. The lowest number of grains panicle ${ }^{-1}$ (106.47) was obtained in 25-day old tiller seedlings of BRRI dhan51 fertilized with prilled urea in two splits (Table 7). The highest number of sterile spikelets panicle ${ }^{-1}$ (21.53) was obtained in 25-day old tiller seedlings of BRRI dhan49 under control treatment and the lowest one (12.30) was obtained in 25-day old tiller seedlings of BRRI dhan49 fertilized with $2.7 \mathrm{~g}$ USG (Table 7). The highest number of total spikelets (153.87) was obtained in 35-day old tiller seedlings of BRRI dhan51 under control treatment and the lowest one (126.81) was obtained in 25-day old tiller seedlings of BRRI dhan51fertilized with prilled urea (Table 7$)$. The highest 1000 -grain weight $(28.10 \mathrm{~g})$ was obtained in 35-day old tiller seedlings of BRRI dhan51 under no urea application and the lowest one $(20.79 \mathrm{~g})$ was obtained in 25-day old tiller seedlings of BRRI dhan51 were fertilized with prilled urea in two splits (Table 7). The highest grain yield $\left(4.86 \mathrm{tha}^{-1}\right)$ was obtained due to the interaction of 35-day old tiller seedlings of BRRI dhan51 fertilized with USG $1.8 \mathrm{~g}$ and the lowest grain yield $\left(2.78 \mathrm{t} \mathrm{ha}^{-1}\right)$ was obtained in 25-day old tiller seedlings of BRRI dhan49 fertilized with two splits of prilled urea (Table 7). The highest straw yield $\left(5.00 \mathrm{t} \mathrm{ha}^{-1}\right)$ was obtained in 35-day old tiller seedlings of BRRI dhan49 fertilized with USG $2.7 \mathrm{~g}$ and the lowest straw yield $\left(3.26 \mathrm{t} \mathrm{ha}^{-1}\right)$ was obtained in 25-day old tiller seedlings of BRRI dhan51 under control treatment (Table 7). The highest harvest index (54.76\%) was obtained in 35-day old tiller seedlings of BRRI dhan51 fertilized with prilled urea in two splits and the lowest harvest index (44.04\%) was obtained in 35-day old tiller seedlings of BRRI dhan49 fertilized prilled urea in two splits (Table 7). 
Table 7. Effect of interaction of variety, age of tiller seedlings and nitrogen management on crop characters and yield of transplant Aman rice

\begin{tabular}{|c|c|c|c|c|c|c|c|c|c|c|c|c|}
\hline $\begin{array}{c}\text { Interaction } \\
\text { (varietyX age of tiller } \\
\text { seedlingsX nitrogen } \\
\text { management) }\end{array}$ & $\begin{array}{l}\text { Plant } \\
\text { height } \\
(\mathrm{cm})\end{array}$ & $\begin{array}{l}\text { No. of total } \\
\text { tillers } \\
\text { hill-1 }\end{array}$ & $\begin{array}{l}\text { No. of } \\
\text { effective } \\
\text { tillers hill-1 }\end{array}$ & $\begin{array}{l}\text { No. of non- } \\
\text { effective tillers } \\
\text { hill-1 }^{-1}\end{array}$ & $\begin{array}{l}\text { Panicle } \\
\text { length } \\
\text { (cm) }\end{array}$ & $\begin{array}{c}\text { No. of grains } \\
\text { panicle-1 }^{-1}\end{array}$ & $\begin{array}{l}\text { No. of sterile } \\
\text { spikelets } \\
\text { panicle-1 }\end{array}$ & $\begin{array}{l}\text { No. of total } \\
\text { spikelets } \\
\text { panicle-1 }\end{array}$ & $\begin{array}{l}\text { 1000-grain } \\
\text { weight }(\mathrm{g})\end{array}$ & $\begin{array}{l}\text { Grain } \\
\text { yield } \\
\left(\mathrm{t} \mathrm{ha}^{-1}\right)\end{array}$ & $\begin{array}{l}\text { Straw } \\
\text { yield } \\
\left(\mathrm{t} \mathrm{ha}^{-1}\right)\end{array}$ & $\begin{array}{c}\text { Harvest } \\
\text { index } \\
(\%)\end{array}$ \\
\hline$V_{1} \times A_{1} \times N_{1}$ & 108.06 & $11.90 a b c$ & $10.10 \mathrm{~cd}$ & 1.80 & 26.80 & $113.51 \mathrm{cde}$ & 17.59abcdef & 131.10bcd & $22.40 \mathrm{de}$ & $3.08 \mathrm{ef}$ & 3.63ab & $46.09 \mathrm{ab}$ \\
\hline$V_{1} X A_{1} \times N_{2}$ & 11044 & $660 \mathrm{fa}$ & $500 \mathrm{f}$ & 160 & 2542 & 123.23abcde & $1763 \mathrm{abcdef}$ & $14086 a b c d$ & $24.07 \mathrm{bcd}$ & 3.16def & $3.91 a b$ & $4476 \mathrm{~b}$ \\
\hline $\mathrm{V}_{1} \times \mathrm{A}_{1} \times \mathrm{N}_{3}$ & 107.56 & $13.80 \mathrm{ab}$ & 11.10abc & 2.70 & 27.62 & 130.83abc & $12.93 \mathrm{def}$ & 143.76abcd & 25.39abcd & 4.06abcde & 4.66ab & $47.59 \mathrm{ab}$ \\
\hline$V_{1} \times A_{1} \times N_{4}$ & 107.66 & 7.46efg & $5.80 \mathrm{ef}$ & 1.66 & 26.96 & 126.64abcd & $14.07 \mathrm{cdef}$ & 140.71abcd & 25.42abcd & $4.35 \mathrm{abc}$ & 4.33ab & $50.00 \mathrm{ab}$ \\
\hline $\mathrm{V}_{1} \times \mathrm{A}_{1} \times \mathrm{N}_{5}$ & 106.56 & $14.17 \mathrm{ab}$ & $12.90 \mathrm{ab}$ & 1.26 & 29.10 & $138.83 a b$ & $12.30 f$ & $151.13 a$ & $26.53 \mathrm{ab}$ & $4.46 \mathrm{ab}$ & $4.30 \mathrm{ab}$ & 50.98ab \\
\hline$V_{1} \times A_{2} \times N_{1}$ & 101.66 & 7.40efg & $5.73 \mathrm{ef}$ & 1.66 & 23.77 & 122.06abcde & 17.78abcdef & 139.84abcd & $22.67 \mathrm{cde}$ & $3.58 \mathrm{bcdef}$ & $3.86 a b$ & 48.14ab \\
\hline$V_{1} \times A_{2} \times N_{2}$ & 86.30 & 7.93efg & $5.80 \mathrm{ef}$ & 2.13 & 22.75 & 121.34abcde & 16.99abcdef & 138.33abcd & $24.03 \mathrm{bcd}$ & 3.41cdef & 4.33ab & $44.04 b$ \\
\hline $\mathrm{V}_{1} \times \mathrm{A}_{2} \times \mathrm{N}_{3}$ & 94.50 & 11.33bcd & $9.60 \mathrm{~cd}$ & 1.73 & 23.07 & 132.18ab & 12.84def & 145.02ab & $25.69 \mathrm{abc}$ & 3.96abcde & 4.23ab & $48.15 \mathrm{ab}$ \\
\hline $\mathrm{V}_{1} \times \mathrm{A}_{2} \mathrm{XN}_{4}$ & 98.83 & 7.70efg & $6.50 \mathrm{ef}$ & 1.20 & 25.43 & 124.43abcde & 17.27abcdef & 141.70abcd & $26.03 \mathrm{ab}$ & 3.80bcdef & 3.83ab & 49.52ab \\
\hline $\mathrm{V}_{1} \times \mathrm{A}_{2} \mathrm{XN}_{5}$ & 92.63 & $14.47 \mathrm{a}$ & $13.23 a$ & 1.23 & 28.80 & $139.13 a$ & 12.80def & $151.93 a$ & $26.00 \mathrm{ab}$ & $4.46 a b$ & $5.00 \mathrm{a}$ & $47.27 \mathrm{ab}$ \\
\hline $\mathrm{V}_{2} \times \mathrm{A}_{1} \times \mathrm{N}_{1}$ & 97.59 & 7.25efg & $5.74 \mathrm{ef}$ & 1.51 & 22.14 & $107.20 \mathrm{e}$ & $21.53 a$ & $128.73 \mathrm{bcd}$ & $24.13 \mathrm{bcd}$ & $3.41 \mathrm{cdef}$ & $3.26 \mathrm{~b}$ & 51.82ab \\
\hline $\mathrm{V}_{2} \mathrm{XA}_{1} \times \mathrm{N}_{2}$ & 100.08 & $9.90 \mathrm{cde}$ & $7.83 \mathrm{de}$ & 2.06 & 22.68 & $106.47 \mathrm{e}$ & $20.34 a b$ & $126.81 d$ & $20.79 \mathrm{e}$ & $2.78 f$ & $3.51 \mathrm{ab}$ & $45.32 a b$ \\
\hline $\mathrm{V}_{2} \times \mathrm{A}_{1} \times \mathrm{N}_{3}$ & 95.52 & $13.07 \mathrm{ab}$ & $10.60 \mathrm{bc}$ & 2.46 & 25.13 & 131.53abc & $12.53 \mathrm{ef}$ & $144.06 \mathrm{abc}$ & $25.58 \mathrm{abc}$ & $4.36 \mathrm{abc}$ & $3.96 a b$ & $52.64 \mathrm{ab}$ \\
\hline $\mathrm{V}_{2} \mathrm{XA}_{1} \times \mathrm{N}_{4}$ & 92.73 & 8.60defg & $6.93 \mathrm{ef}$ & 1.66 & 22.89 & 120.40bcde & $18.55 \mathrm{abcd}$ & 138.96abcd & $23.56 \mathrm{bcde}$ & 3.86abcde & 3.83ab & $50.20 \mathrm{ab}$ \\
\hline $\mathrm{V}_{2} \mathrm{XA}_{1} \mathrm{XN}_{5}$ & 88.76 & 13.90ab & $12.70 \mathrm{ab}$ & 1.20 & 28.46 & 137.90ab & $12.53 \mathrm{ef}$ & $150.43 a$ & $25.53 a b c$ & $4.50 \mathrm{ab}$ & $4.63 a b$ & $49.30 \mathrm{ab}$ \\
\hline $\mathrm{V}_{2} \times \mathrm{A}_{2} \times \mathrm{N}_{1}$ & 87.96 & $9.20 \mathrm{cdef}$ & $7.60 \mathrm{de}$ & 1.60 & 22.06 & 138.83ab & $15.03 \mathrm{bcdef}$ & $153.87 a$ & $28.10 \mathrm{a}$ & $4.5 \mathrm{ab}$ & $4.98 a$ & 51.33ab \\
\hline $\mathrm{V}_{2} \mathrm{XA}_{2} \mathrm{XN}_{2}$ & 82.30 & $5.80 \mathrm{~g}$ & $4.46 f$ & 1.33 & 22.58 & 133.07ab & 18.29abcde & $151.36 \mathrm{a}$ & $25.08 \mathrm{abcd}$ & 4.16abcd & $3.50 \mathrm{ab}$ & $54.76 a$ \\
\hline $\mathrm{V}_{2} \mathrm{XA}_{2} \mathrm{XN}_{3}$ & 85.93 & $7.00 \mathrm{fg}$ & 5.53ef & 1.46 & 21.81 & 112.06de & $15.09 \mathrm{bcdef}$ & $127.16 \mathrm{~cd}$ & $22.77 \mathrm{cde}$ & $3.08 \mathrm{ef}$ & $3.65 a b$ & 46.30ab \\
\hline $\mathrm{V}_{2} \times \mathrm{A}_{2} \times \mathrm{N}_{4}$ & 88.60 & 9.13cdef & $6.73 \mathrm{ef}$ & 2.40 & 22.13 & 121.56abcde & $19.04 \mathrm{abc}$ & 140.60abcd & $23.44 \mathrm{bcde}$ & $4.86 a$ & $4.16 a b$ & $47.35 \mathrm{ab}$ \\
\hline $\mathrm{V}_{2} \mathrm{XA}_{2} \mathrm{XN}_{5}$ & 92.13 & $13.87 \mathrm{ab}$ & $12.83 a b$ & 1.03 & 28.80 & $137.30 \mathrm{ab}$ & $12.36 f$ & $149.66 a$ & $25.76 \mathrm{abc}$ & $3.66 \mathrm{bcdef}$ & 4.51ab & 49.96ab \\
\hline CV (\%) & 7.93 & 8.15 & 9.83 & 31.29 & 5.57 & 8.93 & 22.46 & 7.29 & 7.67 & 8.15 & 9.49 & 11.72 \\
\hline Level of sig. & NS & $* *$ & $* *$ & NS & NS & $*$ & $*$ & $* *$ & * & $* *$ & $*$ & $*$ \\
\hline
\end{tabular}

In a column, figures having similar letter(s) do not differ significantly whereas the figures with dissimilar letter(s) differ significantly as per DMRT

NS indicates not significant $A_{1}=25$-day old tiller seedling $\quad N_{1}=$ Control (no urea)

* indicates significant at $5 \%$ level of probability

** indicates significant at $1 \%$ level of probability

A2 = 35-day old tiller seedling; $\quad N_{2}=$ Prilled urea(1/2 at15 DAT $+1 / 2$ at 30 DAT)

$\mathrm{V}_{1}=$ BRRI dhan $49, \mathrm{~V}_{2}=$ BRRI dhan 51

$\mathrm{N}_{3}=$ Prilled urea (1/3 at15 DAT+1/3 at $30 \mathrm{DAT}+1 / 3$ at 45DAT)

$\mathrm{N}_{4}=$ USG $1.8 \mathrm{~g}$

$\mathrm{N}_{5}=$ USG $2.7 \mathrm{~g}$ 


\section{Conclusion}

The results revealed that BRRI dhan51 had better performance than BRRI dhan49 in terms of grain yield. Older tiller seedlings (35-day old) gave higher grain yield compared to younger ones. Application of $1.8 \mathrm{~g}$ USG four-hill ${ }^{-1}$ in every alternate row produced higher grain yield among the treatments. From the results it can, therefore, be concluded that 35-day tiller seedlings of BRRI dhan51 while fertilized with USG $1.8 \mathrm{~g}$ appears to be a management practice of rice in Aman season.

\section{References}

Ahmed, M.H., Islam, M.A., Kader, M.A. and Anwar, M.P. 2000. Evaluation of urea super granules as source of nitrogen in transplant aman rice. Pakistan J. Biol. Sci. 3(5): 735-737.

Anwar. M.P. Begum, M. 2004. Tolerance of hybrid rice variety sonarbangla1 to tiller separation. Bangladeshj. Crop science 13 (2): 39-44.

BBS (Bangladesh Bureau of Statistics). 2011. Statistical Year Book of Bangladesh Bureau of Statistics, Stat. Div., Minis. Plan., Govt. People's Repub. Bangladesh, Dhaka.pp.47-50.

Bhowmick, N. and Nayak, R.L. 2000. Response of hybrid rice (Oryza sativa) varieties to nitrogen, phosphorus and potassium fertilizers during dry season in West Bengal. Indian J. Agron. 45(2): 323- 326.

Biswas, P.K. and Salokhe, V.M. 2001. Effects of planting date, intensity of tiller separation and plant density on the yield of transplanted rice. The journal of Agricultural science 137: 279-287.

Biswas, P.K., Roy, S.K. and Quasem, A. 1987. Yield ability of tiller separated from standing transplanted aman rice and replanted. Intl. Rice Res. Newsl. 14 (2): 26.

BRRI (1988). Annual Report of BRRI, Joydevpur, Gazipur, Dhaka. pp. 8, 11-12.

Chowdhury, M.J.U., Sarker, A.U., Sarkar, M.A.R. and Kashem, M.A. 1993. Effect of variety and number of seedlings hill ${ }^{-1}$ on the yield and its components on late transplanted aman rice. Bangladesh J. Agril. Sci. 20 (2): 311-316.

Gomez, K.A. and Gomez, A.A. 1984. Duncan's, Muitiple Range Test. Statistical Procedures for Agril. Res. $2^{\text {nd }}$ Edn. AWiley InterScience puboication, John Wiley and Sons, New York. pp. 202-215.

Hanada, K. 1979. Differentiation and development of tiller buds in rice plants. J. A. R. Q. 16:79-86.

Hossain, S.M.A. and Islam, M.S. 1986. Fertilizer management in Bangladesh. Advances in Agronomic Research in Bangladesh. Bangladesh Soc. Agron. Joydebpur, Bangladesh, pp. 48-54.

Khisha, K. 2002. An Evaluation of Madagascar System of Rice production in aman Season with Three High potential Rice Varieties. MS Thesis, Dept. Agron., Bangladesh Agril. Univ., Mymensingh. p. 98.

Langer, R.H.M. 1979. Tillering In: how grasses grow ( $2^{\text {nd }}$ ed.). Studies in Biology. No.34, Edward Annold, London, p. 67.

Mridha, M.A., Nasiruddin, J.M. and Siddique, S.B. 1991. Tiller separation on yield and are covered in rice. Proc. of the $16^{\text {th }}$ Ann. BAAS conf held on 5-7 July 1991, Dhaka. p.67.

Paul, S.K., Sarkar, M.A.R., and Ahmed, M. 2002. Effect of row arrangement and tiller separation on the yield and yield components of transplant aman rice. Pakistan Journal of Agronomy, 1 (1): 9-11.

Prasad, R. and De Datta S.K. 1979. Increasing fertilizer nitrogen efficiency in wetland rice. In: Nitrogen and Rice Intl. Rice Res. Inst., Los Banos, Philippines, pp: 465-479.

Rahman, M.A. 2003. Effect of levels of urea super granules and depth of placement on the growth and yield of transplant aman rice. MS (Ag.) Thesis, Dept. Agron., Bangladesh Agril, Univ., Mymensingh. 100 p.

Roy, B. 1985. Nitrogen use efficiency in transplanted rice with point placement methos. Oryza, 22: 53-56.

Sarkar, M.A.R., Paul, S.K. and Hossain, M.A. 2011. Effect of row arrangement, age of tiller seedlings and number of tiller seedlings hill $^{-1}$ on performance of transplant aman rice. J. Agril. Sci. 6 (2): 59-68.

Shamsuddin, A.M., Islam, M.A. and Hossain, A. 1988. Comparative study on the yield and agronomic characters of nine cultivars of aus rice. Bangladesh J. Agric. Sci. 15 (1): 121-124.

Thakur, R.B. 1993. Performance of summer rice (Oryza sativa) to nitrogen. Indian J. Agron. 36: 229-230.

Tyeb, A., Paul, S.K. and Samad, M.A. 2013. Performance of variety and spacing on the yield and yield contributing characters of transplanted Aman rice. J. Agrofor. Environ. 7 (1): 57-6. 